\section{SPLENIC ANEMIA, OR "BANTI'S DISEASE," COMPLICATED BY DIABETES MELLITUS.}

BY H. A. HARE, M.D.

PROFESSOR OF THERAPEUTICS, JEFFERSON MEDICAL COLLEGE. PHILAUELPHIA.

In the Medical Newus of March 2\%, 189\%, I reported several cases illustrating grave changes in the blood. One of these, it will be recalled, was a man aged 24 years, who had a negative family history and a personal history that he had had double pneumonia in 1894 , and in the same year had fallen a distance of thirty feet while working in a mine, sustaining as a result of this fall severe injury to his head and neck: He was admitted to the Jefferson Hospital in 1895, with the statement that in July of that year he had begun to suffer from severe pain beneath the clavicle of the left side, this extending downward into the left hypochondria $^{3}$. He was exceedingly pale, his conjunctivæ yellow, and the spleen enormously large. The urine was entirely normal. Later on, an examination of his eyes, by Professor de Schweinitz, revealed hemorrhages in the retina of each. An examination of his blood, a detailed record of which will be found in the News as above mentioned, revealed the fact that he had a very great excess of lymphocytes, although the total number of leucocytes was about normal. For a period of two years his leucocytes varied from 8000 to 4000 , usually averaging about 6000 . But his lymphocytes, on Dec. 25,1895 , were 84 per cent.; the mononuclear cells, 4 per cent.; the polynuclear cells, 8 per cent.; and the eosinophiles, 3 per cent. The red cells varied from time to time from $1,000,000$ to $2,800,000$. As already stated, the spleen was enormously enlarged.

The patient has been under observation more or less constantly ever since his original entrance to the hospital in 1895, and in the Medical Nevs of Dec. 24, 1898, I made a further report concerning his condition over and above that already mentioned. In this paper I noted that on Feb. 22, 1898, he gave a history that eight days previously he had a severe attack of nose-bleed, and that his spleen at this time had become painful. The attack of epistaxis became recurrent. His temperature was normal, his pulse 86 , his respirations 22. An examination of his urine at this time, as on all previous occasions, revealed nothing abnormal. On Feb. 23, 1898, his color index was 1.25; hemoglobin, 40 per cent.; red cells, 1,620,000; white cells, 7000. It was only on making a differential count that the marked difference between his condition at this time and at previous observations became notable, for now he was found to have 58 per cent. of polynuclear cells; 17 per cent. of small lymphocytes; 19 per cent. of large lymphocytes: 2 per cent. of transitional ; 2 per cent. of eosinophiles and 2 per cent. of myelocytes. After a considerable residence in the hospital, he left in much better health, and returned in .June, 1898, when his polymorphonuclear cells were 66 per cent.; his lymphocytes, 26 per cent.; eosinophiles, 4 per cent.; transitional cells, 2 per cent.; myelocytes, 2 per cent., and in addition it was noted that there were poikilocytes, macrocytes, microcytes, normoblasts and gigantoblasts. His hemoglobin was 25 per cent.; his red cells $\cdot 1,800,000$ and the white ones 7000 .

This patient again came under my observation on Nov. 13, 1898, stating that he had been suddenly attacked two weeks before with a profuse flow of urine;

1 See photograph of patient, with size of spleen outlined, in the Medical News, March 27, and in the author's book on Diagnosis. that he presented himself at one of the hospitals of this city, where it had been found that his urine contained large quantities of sugar, and when the quantity of his urine and the quantity of sugar which it contained was measured, he found he was passing ten quarts in twenty-four hours, and was told by a homeopath physician who made the analysis that he was passing a pound of sugar a day. When he learned this, he came to my office in order that I might prescribe for him, and I confess that I was decidedly skeptical when he informed me of the quantities of urine which he was passing and the quantity of sugar which he had been told it contained. I therefore directed him to bring his urine to me, and found that he was actually passing 30 grains of sugar to the ounce. As it was not possible for me to have a blood-count made on the day of his visit, I arranged with him to return the next day, but this he failed to do, and I have not been able to find him since that time. He told me on the occasion of his visit that up to the time of the beginning of this diabetic attack he had gained weight considerably, and had been working for a number of weeks in a barber shop where he was constantly on his feet from 7 a.m. till 9 p. m., and that until the glycosuria developed, he had actually gained weight, and was feeling better than he had felt for a considerable period of time.

This patient's condition always improved very greatly when large doses of arsenic were given him, and his periods of relapse were usually precipitated by hard work, exposure, or poor food. By the use of rest, good food, arsenic and various preparations of iron, he was markedly improved in his condition each time that he was under my observation. Aside from the very curious blood conditions which have been present in him, and which made his case decidedly unusual, the onset of such a profound degree of diabetes mellitus is exceedingly interesting. Whether there is any connection between the two diseases, I am unable to state, and so far as I know, no reports are on record in which the two conditions existed side by side.

\section{DIAGNOSIS OF INTSTINAL PERFORATION BY MEANS OF ETHER INFLATION PER RECTUM.* \\ BY E. M. SUTTON, M.D. PEORIA, ILL. \\ About two years ago I conceived the idea of utilizing} ether vapor as a means of diagnosing intestinal perforation, and made some experiments therewith, the results of which were published in the Journat, vol. xxxi, p. 191. I now desire to report a practical application in the case of a gunshot wound of the abdomen.

Mrs. S., on the morning of Sept. 1, 1899, was shot in the abdomen with a 32-caliber revolver, from a distance of about ten feet. The external wound was two inches below and one inch to the right of the umbilicus, taking an upward, inward course through the very thick walls. She suffered from shock, but not severely; after removal in the ambulance, to St. Francis Hospital, and placing her on the operating table, nausea developed. The bowels were then inflated with the vapor of ether and the infiltration continued until the patient belched ether from the stomach-readily recognized by Drs. DuMars and Studer and myself-and the diagnosis of penetrating wound of the abdomen without intestinal perforation was made.

The ball entered the peritoneal cavity, passed above

* Read before the Peorla Medical Soclety, Sept. 5, 1899. 